\title{
PEMBERDAYAAN MASYARAKAT NELAYAN DI KABUPATEN PASURUAN: KAJIAN PENGEMBANGAN MODEL PEMBERDAYAAN SUMBERDAYA MANUSIA DI WILAYAH PESISIR PANTAI
}

\author{
Matheus Nugroho*) \\ *) Dosen Program Studi Teknologi Hasil Perikanan Universitas Yudharta Pasuruan, \\ e-mail:mtnugroho@gmail.com
}

\begin{abstract}
Abstrak
Tujuan yang ingin dicapai dalam penelitian pengabdian masyarakat civitas akademika Universitas Yudharta adalah (1) untuk mengetahui pola hidup nelayan (kondisi sosial, ekonomi dan budaya), dan upaya pendekatan ilmu pengetahuan dan teknologi apa saja yang dapat dilakukan untuk merubah kehidupan yang lebih baik; (2) untuk mengetahui modal usaha yang dimiliki nelayan, dan upaya ilmu pengetahuan dan teknologi apa saja yang dapat dilakukan untuk merubah kehidupan yang lebih baik; (3) untuk merumuskan konsep kebijakan pemberdayaan masyarakat nelayan yang tepat, untuk merubah kehidupan nelayan yang lebih baik. Metode penelitian yang digunakan dalam kegiatan pengabdian masyarakat ini action research, dengan fokus (1) pola hidup nelayan (kondisi sosial, ekonomi dan budaya); (2) modal usaha yang dimiliki nelayan dan (3) konsep kebijakan pemberdayaan masyarakat nelayan. Hasil penelitian menunjukkan bahwa (1) pola hidup nelayan, yaitu interaksi sosial dan budaya masyarakat nelayan Kabupaten Pasuruan masih kuat, sementara tingkat pendapatan dan kesempatan berusaha masih rendah. Metode pelatihan dan pengembangan diversifikasi usaha produk perikanan dapat meningkatkan pendapatan ekonomi nelayan; (2) modal usaha nelayan yaitu aset yang dimiliki nelayan dan peluang pengembangannya, manajemen modal usaha nelayan serta akseptabilitas pengembangan modal usaha belum memberikan pengaruh terhadap peningkatan pendapatan ekonomi masyarakat nelayan. Metode pelatihan dan pengembangan manajemen kewirausahaan ekonomi mikro dapat meningkatkan pendapatan ekonomi nelayan; (3) konsep kebijakan pengembangan ekonomi produktif usaha pengolahan hasil perikanan yang berkelanjutan, dengan metode pelatihan dan pendampingan keluarga nelayan dapat meningkatkan kesejahteraan masyarakat nelayan.
\end{abstract}

Kata kunci: pemberdayaan masyarakat nelayan, pola hidup nelayan, modal usaha nelayan

\begin{abstract}
Objectives to be achieved in the academic community of the University community service Yudharta were to determine the pattern of fishing life (social, economic and cultural), and the approach to the science and technology what can be done to change lives for the better; to determine the capital owned by fishermen, and the efforts of science and technology was what can be done to change a better life, to formulate the concept of community empowerment policy fishermen the right, to change lives better fisherman. Research methods used in community service activities this action research, with a focus on the pattern of fishing life (social, economic and cultural), capital owned fishing effort and the concept of community empowerment policy fishermen. The results showed that fishing lifestyle, the social and cultural interaction Pasuruan fishing community was still strong, while the level of income and business opportunities were still low. The training and development of fishery products diversification can increase the economic income of fishermen, the fishing capital assets and development opportunities fisherman, fishermen venture capital management and capital development acceptability has not given effect to increase the economic income of the fishermen
\end{abstract}


community. Methods of training and development of microeconomic entrepreneurial management can increase the economic income of fishermen; the concept of productive economic development policies fish processing enterprises sustainable, with training and mentoring methods can improve the welfare of families of fishermen fishing communities.

Keywords: empowerment of fishing communities, fishing lifestyle, fishermen venture capital

\section{PENDAHULUAN}

Pengembangan sumberdaya manusia yang paling berpengaruh adalah pendidikan, menurut Ginting (2006) pendidikan adalah sangat berhubungan dengan perubahan Knowledge, Skill, dan Attitude. Sumitro (1994) menyatakan bahwa sumberdaya manusia merupakan prasyarat untuk meningkatkan martabat manusia. Melalui pendidikan, warga masyarakat mendapat kesempatan untuk membina kemampuannya dan mengatur kehidupannya. Pengembangan pendidikan sumberdaya manusia adalah membangun manusia agar mampu untuk membangun dirinya sendiri, dalam arti mengenali potensi diri, kendala yang dihadapi dan mampu memformulasikan solusi kendala tersebut, tentunya dengan bantuan fasilitator. Dalam kaitannya dengan membangun sumber daya manusia pesisir ini, maka pada umumnya masyarakat telah bergabung dalam wadah kelompok nelayan (Suhaeti dan Basuno, 2003).

Mubyarto et al. (1984:10) menyatakan bahwa sebutan masyarakat pesisir atau nelayan selalu menunjuk pada lapisan kelompok masyarakat yang identik kebodohan dan keterbelakangan. Tingkat pendidikan dan ketrampilan yang mereka miliki masih sangat rendah (Sawit, 1988:16). Pendidikan sumberdaya manusia mempunyai peranan penting dalam pengelolaan sumberdaya alam pesisir, sebab pada hakekatnya manusia di kawasan pesisir sebagai kontrol terhadap pemanfaatan sumberdaya alam yang dilakukan secara bijaksana dengan mengindahkan kaidah kelestarian lingkungan (Supriharyono, 2005). Pendekatan pemberdayaan masyarakat melalui ilmu pengetahuan dan teknologi yang berbasis kondisi masyarakat nelayan tentunya dapat memberikan peranan kepada setiap individu masyarakat nelayan bukan hanya sebagai obyek, tetapi sebagai pelaku (aktor) yang menentukan hidup mereka (Moebyarto, 1996).

Masyarakat yang tinggal di wilayah pesisir pantai di Indonesia dikenal sebagai kawasan masyarakat miskin, kumuh dan terbelakang. Kondisi ini sangat ironis apabila dibandingkan dengan keadaan alam wilayah pesisir yang yang kaya akan sumberdaya alam dan potensial dikembangkan secara ekonomi. Menurut Siahaan (Islamy et al., 2004) di daerah pesisir, umumnya merupakan kantong-kantong kemiskinan struktural yang sangat kronis. Yaitu kemiskinan yang ditimbulkan akibat adanya tekanan ekonomi dan eksploitasi dari kelompok masyarakat, sehingga nelayan miskin tetap menjadi sangat "marginal".

Pesisir pantai Kabupaten Pasuruan menyimpan potensi sumberdaya alam yang sangat besar. Potensi kelautan dan perikanan yang terdapat di Kabupaten Pasuruan 
meliputi wilayah perairan laut yang terbentang sepanjang $\pm 48 \mathrm{~km}$ mulai dari kecamatan Nguling sampai Bangil. Potensi laut dan pantai dengan luas wilayah eksploitasi 112,5 mil laut persegi menghasilkan potensi lestari 49,51 ribu ton ikan per tahun. Dari potensi yang ada baru dapat dieksploitasi sebesar 10.403,4 ton. Pengembangan penangkapan ikan dilaut diarahkan untuk mengoptimalkan potensi yang ada terutama wilayah Kecamatan Nguling, Lekok dan Kraton (DKP Kabupaten Pasuruan, 2012).

Pada tahun 2012 usaha budidaya tambak mencapai luasan 3966,9 Ha yang tersebar di 5 kecamatan dengan jumlah pembudidaya tambak 1722 petani ikan. Komoditi tambak meliputi udang dan bandeng dengan total produksi mencapai 4285,3 ton ikan per tahun. Selain udang dan bendeng untuk menunjang kebutuhan eksport saat ini dikembangkan adalah budidaya rumput laut. Budidaya ikan air tawar di kolam tersebar di 19 kecamatan dengan luas lahan 30,5 Ha. Jenis ikan yang dibudidayakan antara lain lele, nila, tombro, gurami, patin, bawal dan mujaer dengan jumlah produksi mencapai 103,7 ton.Untuk memenuhi kebutuhan benih ikan terdapat unit pembenihan rakyat. Selain itu juga dibangun balai benih ikan yang telah beroperasi saat ini. Budidaya ikan air tawar juga berfungsi untuk meningkatkan pendapatan dan pemanfaatan lahan pekarangan sebagai usaha sambilan rumah tangga. Diversifikasi usaha juga dilakukan dengan mengembangkan budidaya ikan hias seperti ikan koki, koi, black moly dan red fin. Budidaya karamba di Kabupaten Pasuruan selama ini telah dilakukan di Kecamatan Beji dan Grati. Danau Ranu Grati dengan luasan kurang lebih 198 Ha potensial untuk pengembangan usaha ikan di karamba jaring apung. Luas budidaya karamba jaring apung saat ini mencapai 36,6 Ha dengan jumlah pembudidaya sebanyak 237 petani ikan. Produksi yang dihasilkan dari usaha tersebut sebesar 672,2 ton, dengan komoditi andalan ikan nila. Selain nila saat ini juga dikembangkan jenis ikan bandeng tawar, bawal, patin dan lele (DKP Kabupaten Pasuruan, 2012).

Upaya peningkatan ilmu pengetahuan dan teknologi masyarakat nelayan Kabupaten Pasuruan merupakan program yang mutlak dikembangkan sebagai wahana untuk meningkatkan kemampuan sebagai nelayan dan petani ikan, serta tentunya taraf hidup masyarakat nelayan yang tinggal di pesisir pantai Kabupaten Pasuruan. Program pemberdayaan masyarakat nelayan ini, merupakan salah satu visi Program Studi Teknologi Hasil Perikanan Universitas Yudharta Pasuruan, dimana Universitas Yudharta menjadi institusi preservasi dan pusat informasi teknologi perikanan di Kabupaten Pasuruan serta menghasilkan sarjana perikanan profesional, yang mampu berkompetisi di tingkat nasional. Tujuannnya (1) menghasilkan lulusan sarjana perikanan yang berkualitas, integritas moral yang tinggi, inovatif, kreatif, kritis, analitis dan profesional dalam bidang teknologi perikanan; (2) menghasilkan penelitian dan pengabdian kepada masyarakat dengan karya teknologi perikanan yang inovatif dalam rangka berperan terhadap kemajuan dan kemandirian masyarakat nelayan dalam memenuhi kebutuhan dasarnya (pangan, sandang, perumahan, kesehatan, dan pendidikan).

Tujuan yang ingin dicapai dalam penelitian pengabdian masyarakat 
civitas akademika Universitas Yudharta adalah (1) untuk mengetahui pola hidup nelayan (kondisi sosial, ekonomi dan budaya), dan upaya pendekatan ilmu pengetahuan dan teknologi apa saja yang dapat dilakukan untuk merubah kehidupan yang lebih baik; (2) untuk mengetahui modal usaha yang dimiliki nelayan, dan upaya ilmu pengetahuan dan teknologi apa saja yang dapat dilakukan untuk merubah kehidupan yang lebih baik; (3) untuk merumuskan konsep kebijakan pemberdayaan masyarakat nelayan yang tepat, untuk merubah kehidupan nelayan yang lebih baik.

\section{METODE PENELITIAN}

Metode penelitian yang digunakan dalam kegiatan pengabdian masyarakat ini action research, dengan fokus dan indikator penelitian dapat dijelaskan pada Tabel 1 .

Lokasi penelitian di Kecamatan Lekok kabupaten Pasuruan. Waktu penelitian dilaksanakan selama bulan Agustus-Desember 2014. Data dikumpulkan dengan menggunakan metode wawancara, yaitu percakapan secara langsung dengan responden dengan maksud bila ada responden yang kurang jelas dalam menanggapi kuisoner bisa dijelaskan kembali, dan metode kuisoner yang merupakan teknik penyebaran daftar pertanyaan pada seluruh responden yang terpilih. Responden penelitian adalah kelompok masyarakat yaitu nelayan tangkap, nelayan budidaya, nelayan pedagang, nelayan juragan ikan, dan anggota keluarga nelayan yang terlibat langsung dan tidak langsung terhadap peningkatan pendapatan ekonomi masyarakat nelayan.

Tabel 1. Fokus dan indikator penelitian

\begin{tabular}{|c|c|c|}
\hline $\mathrm{NO}$ & Fokus Penelitian & Indikator \\
\hline 1 & $\begin{array}{l}\text { Pola hidup nelayan (kondisi } \\
\text { sosial, ekonomi dan budaya) }\end{array}$ & $\begin{array}{l}\text { - Nilai ikatan sosial kehidupan sehari- } \\
\text { hari } \\
\text { - Kondisi lapangan kerja, kesempatan } \\
\text { berusaha, modal kerja dan sarana } \\
\text { dan prasarana usaha budidaya, } \\
\text { penangkapan dan pengolahan ikan } \\
\text { - Nilai interaksi sosial budaya antara } \\
\text { anggota keluarga dan warga } \\
\text { masyarakat nelayan }\end{array}$ \\
\hline 2 & $\begin{array}{l}\text { Modal usaha yang dimiliki } \\
\text { nelayan }\end{array}$ & $\begin{array}{l}\text { - } \text { Aset yang dimiliki dan peluang } \\
\text { pengembangannya } \\
\text { - Manajemen modal usaha } \\
\text { - } \text { Akseptabilitas pengembangan modal } \\
\text { usaha }\end{array}$ \\
\hline 3 & $\begin{array}{l}\text { Konsep kebijakan } \\
\text { pemberdayaan masyarakat } \\
\text { nelayan }\end{array}$ & $\begin{array}{l}\text { - Usaha perikanan dan peluang } \\
\text { diversifikasinya } \\
\text { - Usaha ekonomi produktif dan } \\
\text { peluang diversifikasinya }\end{array}$ \\
\hline
\end{tabular}


Kegiatan ini dilaksanakan dengan tahapan sebagai berikut:

1. Tahap Pendahuluan

a) Pemetaan kebutuhan program pemberdayaan masyarakat nelayan Kecamatan Lekok Kabupaten Pasuruan;

b) Indentifikasi potensi dan peluang usaha bagi pemberdayaan masyarakat nelayan;

2. Tahap Pelaksanaan Program Pemberdayaan

a) Pengumpulan data responden tahap awal;

b) Pendampingan

c) Pengumpulan data responden tahap akhir

3. Evaluasi dan pelaporan

a) Analisis data;

b) Analisis dan perumusan pengembangan model;

c) Pelaporan

\section{HASIL PENELITIAN}

\section{Pola hidup nelayan}

Masyarakat pesisir sering dinilai sebagai masyarakat yang memiliki pola hidup yang kurang baik. Kondisi lingkungan dan karakteristik masyarakat dinilai mempengaruhi pola hidup masyarakat pesisir dari satu generasi ke generasi berikutnya. Penelitian ini menelaah pola hidup masyarakat pesisir yang terkait dengan ikatan sosial, lapangan kerja dan kesempatan berusaha, interaksi sosial budaya antara anggota keluarga dan warga masyarakat nelayan.

Hampir semua responden memberikan respon bahwa bobot faktor indikator interaksi sosial menunjukkan nilai yang paling tinggi $(\mathrm{X} 1=0,95)$. Hal ini menunjukkan bahwa interaksi sosial masyarakat nelayan Kabupaten Pasuruan masih kuat. Muhammad et al. (2006) menyatakan hasil penelitiannya bahwa aksesibilitas sosial nelayan di pesisir Lekok, Kabupaten Pasuruan, Jawa Timur memiliki bobot faktor sosial yang paling tinggi, artinya ikatan sosialnya masih tinggi. Dalam kehidupan sehari-hari nelayan terdapat berbagai aktivitas sosial diantara nelayan semakin kuat, sebagai contoh kegiatan arisan, gotong-royong dan budaya saling membantu.

Pendapat responden terhadap bobot faktor lapangan kerja dan kesempatan berusaha (X2) memperlihatkan pengaruh sebesar 0,456 terhadap kondisi pendapatan ekonomi masyarakat nelayan. Hal ini menunjukkan bahwa tingkat pendapatan dan kesempatan berusaha masih rendah pada masyarakat nelayan pesisir Kabupaten Pasuruan. Data menunjukan persoalan kemiskinan masyarakat nelayan pesisir Kabupaten Pasuruan adalah rendahnya angka pendapatan perkapita sebagai nelayan atau buruh nelayan, dan buruh bangunan maupun pekerjaan lain, dengan penghasilan kurang Rp 600.000 per bulan. (DKP Kabupaten Pasuruan, 2012). Kondisi ekonomi masyarakat pesisir adalah menjelaskan keterbatasan lapangan kerja dan kesempatan berusaha, modal kerja dan sarana produksi belum sepenuhnya mendukung pengelolaan wilayah pesisir (Abdullah, 1993).

Interaksi sosial budaya antara anggota keluarga dan warga masyarakat nelayan (X3) memberikan pengaruh yang kuat 0,962 terhadap kondisi pola hidup dan pendapatan nelayan. Hal ini memperlihatkan karakter budaya masyarakat nelayan di pesisir Kabupaten Pasuruan masih sangat kuat. Karakter budaya nelayan yang menonjol di pesisir Jawa adalah (1) terdapat interaksi sosial yang intensif antara warga masyarakat, 
yang ditandai dengan efektifnya komunikasi tatap muka, sehingga terjadi hubungan yang sangat erat antara satu dengan yang lainnya; (2) masyarakat nelayan, dalam mencari nafkah mereka menonjolkan sifat gotong-royong dan saling membantu (Sifema, 2002).

\section{Modal usaha yang dimiliki nelayan}

Hasil penelitian berdasarkan pendapat responden menunjukkan bahwa aset yang dimiliki nelayan dan peluang pengembangannya, manajemen modal usaha nalayan dan skseptabilitas pengembangan modal usaha nilai pengaruhnya masih rendah terhadap peningkatan pendapatan ekonomi masyarakat nelayan (X4 = 0,352). Hal ini mengindikasikan aset yang dimiliki nelayan dan usaha untuk pengembangannya belum mendapat bantuan dan pembinaan dari lembaga permodalan formal seperti koperasi nelayan dan bank permodalan pemerintah. Secara kinerja lembaga keuangan mikro lebih terorganisir dibandingkan yang bukan lembaga keuangan mikro, namun fakta di lapangan menunjukkan bahwa lembaga permodalan formal, seperti koperasi masih belum memenuhi keinginan nasabah (tengkulak), terutama pada prosedur, agunan dan bunga (Nugroho et al., 2008).

\section{Konsep kebijakan pemberdayaan masyarakat nelayan}

Berdasarkan pendapat responden menunjukkan bahwa bobot faktor usaha perikanan dan peluang diversifikasinya, serta usaha ekonomi produktif memberikan pengaruh yang signifikan terhadap peningkatan pendapatan ekonomi masyarakat nelayan $(\mathrm{X} 5=0,981)$. Hal ini mengindikasikan bahwa untuk meningkatkan pendapatan ekonomi, nelayan tidak hanya terfokus pada usaha penangkapan ikan saja, melainkan juga dapat diarahkan pada usaha ekonomi produktif diluar bidang penangkapan atau dikenal dengan diversifikasi usaha perikanan. Kusnadi (2002), menjelaskan bahwa keputusan untuk melakukan usaha ekonomi alternatif diluar usaha penangkapan ikan adalah upaya dan pilihan rasional yang akan lebih menguntungkan kepentingan rumah tangganya dalam menjamin kelangsungan hidup dan meningkatkan kualitas kehidupannya.

Kegiatan usaha yang telah berjalan meliputi warung sembako, kedai pesisir, usaha salon, counter HP, menjahit dan usaha tata boga memberikan pengaruh terhadap peningkatan pendapatan keluarga nelayan. Dikalangan nelayan musim menjadi salah satu kendala dalam mengembangkan usaha. Pada musim paceklik ikan, nelayan akan beralih profesi menjadi pedagang ikan atau usaha diluar perikanan. Pada saat ini kegiatan usaha yang dijalankan telah menghasilkan keuntungan sekalipun masih kecil. Hasil evaluasi mendapatkan bahwa upaya peningkatan keuntungan setidaknya membutuhkan pembinaan usaha lanjutan, penambahan modal usaha, dan peningkatan pasar. Peran mahasiswa dan dosen-dosen perikanan Universitas Yudharta sangat bermanfaat untuk keluarga nelayan untuk mengembangkan hasil usahanya.

\section{KESIMPULAN}

1) Pola hidup nelayan, yaitu interaksi sosial dan budaya masyarakat nelayan Kabupaten Pasuruan masih kuat, sementara tingkat pendapatan dan kesempatan berusaha masih rendah. Metode pelatihan dan pengembangan diversifikasi usaha 
produk perikanan dapat meningkatkan pendapatan ekonomi nelayan

2) Modal usaha nelayan yaitu aset yang dimiliki nelayan dan peluang pengembangannya, manajemen modal usaha nelayan serta skseptabilitas pengembangan modal usaha belum memberikan pengaruh terhadap peningkatan pendapatan ekonomi masyarakat nelayan. Metode pelatihan dan pengembangan manajemen kewirausahaan ekonomi mikro dapat meningkatkan pendapatan ekonomi nelayan

3) Konsep kebijakan pengembangan ekonomi produktif usaha pengolahan hasil perikanan yang berkelanjutan, dengan metode pelatihan dan pendampingan keluarga nelayan dapat meningkatkan kesejahteraan masyarakat nelayan

\section{SARAN}

1) Pemberdayaan masyarakat nelayan membutuhkan pendekatan tahapan perubahan sosial yang membutuhkan waktu yang lama, untuk itu program pemberdayaan masyarakat di suatu lokasi seharusnya berkelanjutan, dengan tahapan yang terencana dengan baik

2) Pola pendampingan lebih baik apabila dibuat dalam bentuk pelatihan, pembinaan dan pendekatan metode oleh peneliti, sehingga perkembangan masyarakat binaan dapat teramati dan mendapatkan treatmen oleh peneliti dengan baik.

3) Keberadaan dan keterlibatan Universitas Yudharta (dosen dan mahasiswa) dalam pemberdayaan masyarakat nelayan Kabupaten
Pasuruan memiliki nilai positif, dan terus ditingkatkan peranannya, baik produktivitas dan kredibilitas serta dievaluasi secara cermat hasilnya.

\section{DAFTAR PUSTAKA}

Abdullah, A. et al. 1993. Pengelolaan hutan mangrove. Jakarta: kantor menteri negara KLH

Dinas Kelautan dan Perikanan Kabupaten Pasuruan, 2012. Laporan tahunan statistik perikanan tangkap Kabupaten Pasuruan Tahun 2012. Pasuruan

Ginting, B., 2006. Pengembangan masyarakat. Makalah disampaikan dalam kuliah di Institut Pertanian Bogor

Islamy, I. 2005. Desain Pemberdayaan Masyarakat nelayan dalam Pengentasan kemiskinan di Indonesia. P3KS Depsos RI, Jakarta.

Kusnadi, M.A., 2002. Akar kemiskinan nelayan. Yogyakarta. LKIS

Mubyarto, L. Soetrisno dan M. Dove, 1984. Nelayan dan kemiskinan : Studi ekonomi antropologi di dua desa pantai. Jakarta : CV. Rajawali. Hal.10

Mubyarto, 1996. Penanggulangan kemiskinan, dalam analisis No. 17 Th. 4 September - Oktober 1996.

Muhammad, S., A.Y. Mashudi dan E. G. Sukoharsono, 2006. Analisis faktor-faktor yang mempengaruhi aksesbilitas sosial ekonomi nelayan kecil di Jawa Timur. Fakultas Perikanan Universitas Brawijaya Malang. Jurnal ilmu-ilmu sosial (social sciences). Vol. 18. No. 1. Hal. 113 
Nugroho, A.S., D.R. Monintja dan H. Hardjomidjojo, 2008. Analisis aplikasi model lembaga keuangan mikro dalam program pemberdayaan ekonomi masyarakat pesisir di Kabupaten Cirebon. Jurnal profesional master program of IPB. P. 1-10

Sawit, H.M., 1988. Nelayan tradisional pantai utara Jawa : dilema milik bersama, dalam masyarakat Indonesia. No. 5. Jakarta : LIPI. Hal. 16

Sifema, 2002. Makalah wanita dalam masyarakat nelayan : latar kehiudpan dan potensi pengembangannya, disajikan dalam seminar budaya pesisir dan kondisi potensi kelautan Sumatera Barat, museum Adityawarman Padang, tanggal 29 Agustus 2002, Hal. 3-4

Sumitro, D., 1994. Dasar teori daerah pertumbuhan dan daerah pengembangan. Jakarta. Penerbit LP3ES

Suhaeti dan Basuno, 2003. Integrasi gender dalam penguatan ekonomi masyarakat pesisir. Pusat analisis sosial ekonomi dan kebijakan pertanian Bogor. Badan litbang pertanian. Bogor

Supriharyono, 2005. Rehabilitasi dan konservasi sumberdaya di wilayah pantai. Program doktor MSDP Undip . Tidak dipublikasikan 